\title{
PENGARUH PENERAPAN SISTEM ADMINISTRASI PERPAJAKAN MODERN TERHADAP KEPATUHAN WAJIB PAJAK ORANG PRIBADI (Studi Kasus Pada Kantor Pelayanan Pajak Pratama Kendari)
}

\author{
Nasrullah Dali $^{1}$, Satira Yusuf ${ }^{2}$, Irene Kristi Tandana Lakaba ${ }^{3}$ \\ Jurusan Akuntansi Fakultas Ekonomi dan Bisnis Universitas Halu Oleo Kendari \\ Sulawesi Tenggara
}

\begin{abstract}
ABSTRAK
Penelitian ini bertujuan untuk mengetahui Pengaruh Sistem Administrasi Perpajakan Modern Terhadap Kepatuhan Wajib Pajak Orang Pribadi di KPP Pratama Kendari. Populasi dalam penelitian ini adalah wajib pajak orang pribadi yang bertempat tinggal dan berkedudukan di Kota Kendari yang terdaftar di KPP Pratama Kendari sebanyak 142.428 orang. Metode pengambilan sampel yaitu accidental sampling menggunakan rumus slovin sebanyak 100 orang. Metode pengumpulan data dalam penelitian ini menggunakan kuesioner, wawancara dan dokumentasi. Analisis data menggunakan metode analisis deskriptif dan analisis regresi linear sederhana. Hasil penelitian ini menunjukkan sistem administrasi perpajakan modern berpengaruh positif dan signifikan terhadap kepatuhan wajib pajak orang pribadi. Hal ini menunjukkan bahwa apabila sistem administrasi perpajakan modern berjalan dengan baik maka kepatuhan wajib pajak akan semakin meningkat. Indikator yang dominan mempengaruhi variabel sistem administrasi perpajakan modern adalah integrasi data.
\end{abstract}

Kata Kunci : Administrasi Perpajakan Modern, Kepatuhan, Wajib Pajak Orang Pribadi.

\section{ABSTRACT}

This study aims to determine the effect of modern tax administration systems on individual taxpayer compliance at KPP Pratama Kendari. The population in this study is an individual taxpayer who resides and is domiciled in Kendari City who is registered at KPP Pratama Kendari as many as 142,428 people. The sampling method was accidental sampling using the Slovin formula as many as 100 people. Data collection methods in this study using a questionnaire, interviews and documentation. The data analysis used descriptive analysis method and simple linear regression analysis. The results of this study indicate that the modern tax administration system has a positive and significant effect on individual taxpayer compliance. This shows that if the modern tax administration system runs well, taxpayer compliance will increase. The dominant indicator affecting the variables of the modern tax administration system is data integration.

Keywords: Modern Tax Administration, Compliance, Individual Taxpayer. 
Jurnal Akuntansi dan Keuangan (JAK)

Volume 6, No. 2 Oktober Tahun 2021

Page: 1 - 14

http://ojs.uho.ac.id/index.php/jak-uho/issue/archive

e-ISSN: 2088-4656

\section{PENDAHULUAN}

Indonesia merupakan negara berkembang yang salah satu sumber pendapatanya adalah dari pemungutan pajak, baik dari pajak negara maupun pajak daerah. Pajak bersifat dinamik, mengikuti perkembangan zaman kehidupan sosial dan ekonomi negara serta masyarakatnya. Tuntutan atas peningkatan penerimaan, perbaikan, dan juga perubahan mendasar aspek perpajakan menjadi alasan perlu dilakukannya reformasi perpajakan dari waktu ke waktu, yang berupa penyempurnaan terhadap kebijakan perpajakan dan sistem administrasi perpajakan, agar basis pajak semakin diperluas, sehingga potensi penerimaan pajak yang tersedia dapat dipungut secara optimal dan memberikan pelayanan prima kepada wajib pajak.

Sistem administrasi perpajakan modern merupakan wujud dari hasil reformasi perpajakan yang disempurnakan dan disesuaikan dengan kondisi perpajakan di indonesia secara menyeluruh di berbagai sektor administrasi pajak. Sistem baru ini dimana organisasi dirancang berdasarkan fungsinya akan memungkinkan pemberian pelayanan prima karena adanya staf pendukung pelayanan khusus atau Account Representative (AR) yang dipilih, dan bekerja secara professional dengan kompetensi tinggi yang disertai kompensasi yang memadai. Selain itu, sistem administrasi perpajakan modern juga merangkul kemajuan teknologi terbaru di antaranya melalui pengembangan Sistem Informasi Perpajakan (SIP) dengan pendekatan fungsi menjadi Sistem Administrasi Perpajakan Terpadu (SAPT) yang dikendalikan oleh case management system dalam workflow system dengan berbagai modul otomasi kantor serta berbagai pelayanan dengan basis e-system.

Berikut data tingkat kepatuhan wajib pajak orang pribadi dalam melaporkan SPT di KPP Pratama Kendari dari tahun 2015-2019.

Tabel 1.1

Tingkat Kepatuhan Wajib Pajak Orang Pribadi

Dalam Melaporkan SPT Lima Tahun Terakhir di KPP Pratama Kendari

\begin{tabular}{|c|c|c|c|c|}
\hline Tahun & $\begin{array}{c}\text { Jumlah WP Lapor SPT } \\
\text { (A) }\end{array}$ & $\begin{array}{c}\text { Jumlah } \\
\text { WPOP } \\
\text { (B) }\end{array}$ & $\begin{array}{c}\text { Wajib } \\
\text { SPT } \\
\text { (C) }\end{array}$ & $\begin{array}{c}\text { Tingkat } \\
\text { Kepatuhan }(\%) \\
(\mathrm{A}: \mathrm{Cx} 100 \%)\end{array}$ \\
\hline 2015 & 40,132 & 96,470 & 80,108 & $50 \%$ \\
\hline 2016 & 56,664 & 107,843 & 89,715 & $63 \%$ \\
\hline 2017 & 52,865 & 122,670 & 93,810 & $56 \%$ \\
\hline 2018 & 52,119 & 134,349 & 63,629 & $82 \%$ \\
\hline 2019 & 64,321 & 148,428 & 62,398 & $98 \%$ \\
\hline
\end{tabular}

Sumber Kantor Palayanan Pajak Pratama Kendari, 2020

Tabel 1.1 menjelaskan bahwa tingkat kepatuhan wajib pajak orang pribadi di KPP Pratama Kendari belumlah maksimal karena pada tahun 2016 ke 2017 mengalami penurunan. Pada tahun 2016 tingkat kepatuhan wajib pajak orang pribadi sebesar 63\%, namun pada tahun 2017 mengalami penurunan sampai 56\%. Pemahaman wajib pajak tentang ketentuan umum dan tata cara peraturan perpajakan dan juga pemahaman terhadap penggunaan e-system menjadi faktor utama dalam mempengaruhi tingkat kepatuhan wajib pajak di KPP Pratama Kendari dalam memenuhi kewajibannya dalam membayar pajak. Tujuan dari penelitian ini yaitu untuk 
Jurnal Akuntansi dan Keuangan (JAK)

Volume 6, No. 2 Oktober Tahun 2021

Page: 1 - 14

http://ojs.uho.ac.id/index.php/jak-uho/issue/archive

e-ISSN: 2088-4656

mengetahui pengaruh sistem administrasi perpajakan modern terhadap kepatuhan wajib pajak orang pribadi pada kantor pelayanan pajak pratama kendari.

\section{LANDASAN TEORI DAN HIPOTESIS}

\section{Pengertian Pajak}

Definisi pajak yang dikemukakan oleh Rochmat Soemitro dalam Siti Resmi (2019:1) pajak adalah iuran rakyat kepada kas negara berdasarkan undang-undang (yang dapat dipaksakan) dengan tidak mendapat jasa timbal balik (kontraprestasi) yang langsung dapat ditunjukkan dan yang digunakan untuk membayar pengeluaran umum. Definisi pajak menurut UU Nomor 6 Tahun 1983 tentang Ketentuan Umum dan Tata Cara Perpajakan sebagaimana telah diubah terakhir kali dengan UU No.16 Tahun 2009 (KUP) pasal 1 angka 1 bahwa pajak adalah kontribusi wajib kepada negara yang terutang oleh orang pribadi atau badan yang bersifat memaksa berdasarkan undang-undang, dengan tidak mendapatkan imbalan secara langsung dan digunakan untuk keperluan negara bagi sebesar-besarnya kemakmuran rakyat.

Berdasarkan pengertian-pengertian diatas, maka dapat ditarik kesimpulan bahwa unsurunsur pajak adalah sebagai berikut:

- Iuran masyarakat kepada negara, yang berhak memungut pajak hanyalah negara.

- Berdasarkan Undang-Undang, pajak dipungut berdasarkan kekuatan Undang-Undang serta aturan pelaksanaannya.

- Dalam pembayaran pajak tidak dapat ditunjukkan adanya kontraprestasi individual oleh pemerintah.

- Pajak digunakan untuk kepentingan umum.

- Digunakan untuk pengeluaran-pengeluaran yang bermanfaat bagi masyarakat luas.

2. Fungsi Pajak

Dalam Siti Resmi (2019:3) terdapat dua fungsi pajak, yaitu :

- Fungsi Budgetair (Sumber Keuangan Negara)

Pajak mempunyai fungsi budgetair, artinya pajak merupakan salah satu sumber penerimaan pemerintah untuk membiayai pengeluaran, baik rutin maupun pembangunan. Sebagai sumber keuangan negara, pemerintah berupaya memasukkan uang sebanyak-banyaknya uang kas negara.

- Fungsi Regularend (Pengatur)

Pajak mempunyai fungsi pengatur, artinya pajak sebagai alat untuk mengatur atau melaksanakan kebijakan pemerintah dalam bidang sosial dan ekonomi serta mencapai tujuan-tujuan tertentu di luar bidang keuangan.

\section{Syarat Pemungutan Pajak}

Agar pemungutan pajak tidak menimbulkan hambatan, maka pemungutan pajak harus memenuhi syarat sebagai berikut (Awaluddin, 2017:4):

- Pemungutan pajak harus adil.

- Pemungutan pajak harus berdasarkan undang-undang di Indonesia, pajak diatur dalam UUD 1945 pasal 23 ayat 2.

- Tidak mengganggu perekonomian.

- Pemungutan pajak harus efisien. 
- Sistem pemungutan pajak harus sederhana.

\section{Reformasi Perpajakan}

Menurut Anggito Abimanyu (2003) reformasi perpajakan adalah perubahan yang mendasar di segala aspek perpajakan. Reformasi perpajakan yang sekarang menjadi prioritas menyangkut modernisasi administrasi perpajakan jangka menengah (tiga hingga enam tahun) dengan tujuan tercapainya: pertama, tingkat kepatuhan sukarela yang tinggi. Kedua, kepercayaan terhadap administrasi perpajakan yang tinggi. Dan, ketiga, produktivitas aparat perpajakan yang tinggi.

\section{Administrasi Perpajakan}

Menurut Gunadi (2006), administrasi pajak dalam arti sempit merupakan penatausahaan dan pelayanan atas hak-hak dan kewajiban pembayaran pajak, baik penatausahaan dan pelayanan yang dilakukan di kantor pajak maupun di tempat wajib pajak, sedangkan administrasi pajak dalam arti luas meliputi fungsi, sistem dan organisasi atau kelembagaan.

\section{Reformasi Administrasi Perpajakan}

Menurut Chaizi Nusucha (2004:37), reformasi administrasi perpajakan adalah penyempurnaan atau perbaikan kinerja administrasi, baik secara individu, kelompok, maupun kelembagaan agar lebih efisien, ekonomi dan cepat. Terdapat dua tugas utama dari reformasi administrasi perpajakan adalah untuk mencapai efektivitas yang tinggi, yaitu kemampuan untuk mencapai tingkat kepatuhan yang tinggi dan efisiensi berupa kemampuan untuk membuat biaya administrasi per unit penerimaan pajak sekecil-kecilnya.

\section{Sistem Administrasi perpajakan Modern}

Menurut Sari (2013:14) mendefinisikan bahwa sistem modernisasi administasi perpajakan adalah Penggunaan sarana dan prasarana perpajakan yang baru dengan memanfaatkan perkembangan ilmu dan teknologi. Jiwa dari program modernisasi ini adalah pelaksanaan good governance yaitu penerapan sistem administasi perpajakan yang transparan dan akuntable dengan memanfaatkan sistem informasi teknologi yang handal dan terkini.

\section{Kepatuhan Wajib Pajak}

Menurut Rahayu (2010:138-140) wajib pajak yang patuh yaitu wajib pajak yang taat dan mematuhi serta melaksanakan kewajiban perpajakan sesuai dengan ketentuan peraturan perundang-undangan perpajakan. Kepatuhan wajib pajak dipengaruhi oleh beberapa faktor yaitu kondisi sistem administrasi perpajakan suatu negara, pelayanan pada wajib pajak, penegakan hukum perpajakan, pemeriksaan pajak, dan tarif pajak.

\section{Pengujian Hipotesis}

Hipotesis merupakan dugaan sementara yang mungkin benar dan mungkin salah, sehingga dapat dianggap atau dipandang sebagai kesimpulan yang sifatnya sementara, sedangkan penolakan atau penerimaan suatu hipotesis tersebut tergantung dari hasil penelitian terhadap faktor-faktor yang dikumpulkan,kemudian diambil kesimpulan (Sugiyono,2015).

Sehubungan dengan uraian diatas dapat dikemukakan hipotesis dalam penelitian ini adalah sebagai berikut :

H1 : Sistem administrasi perpajakan modern memiliki pengaruh signifikan terhadap kepatuhan wajib pajak orang pribadi. 


\section{METODE PENELITIAN}

Penelitian ini dilakukan di Kantor Pelayanan Pajak Pratama Kendari yang berlokasi di jalan Sao-Sao No. 188, Kelurahan Bende, Kecamatan Kadia, Kota Kendari, Provinsi Sulawesi Tenggara. Adapun objek penelitian ini adalah sistem administrasi perpajakan modern dan kepatuhan wajib pajak orang pribadi.

Populasi dalam penelitian ini adalah Wajib Pajak Orang Pribadi terdaftar di Kantor Pelayanan Pajak Pratama Kendari pada tahun 2019 dengan jumlah 148,428. Metode pengambilan sampel menggunakan Accidental Sampling menggunakan rumus Slovin sebanyak 100 sampel. Menurut Sugiyono (2017:62) Accidental Sampling adalah pengambilan sampel secara accidental dengan mengambil responden yang kebetulan atau tersedia disuatu tempat sesuai dengan konteks penelitian.

Jenis data yang digunakan dalam penelitian ini yaitu data kuantitatif. Data kuantitatif dalam penelitian ini yaitu berupa nilai skor atas jawaban yang diberikan responden terhadap pertanyaan-pertanyaan yang ada pada kuesioner.

Sumber data yang digunakan dalam penelitian ini adalah data primer dan data sekunder. Data primer yang dihasilkan penelitian ini adalah data hasil tanggapan responden terhadap variabel-variabel yang akan diuji dalam penelitian ini Sedangkan Data sekunder dalam penelitian ini adalah data-data dokumen yakni profil dan sejarah KPP Pratama Kendari, jumlah wajib pajak yang terdaftar di KPP Pratama Kendari, jumlah wajib pajak lapor SPT, jumlah WP wajib SPT dan sumber lainnya yang berkaitan dengan topik dalam penelitian ini.

Metode pengumpulan data yang dilakukan dalam penelitian ini yaitu : 1) kuesioner, Peneliti menggunakan teknik ini untuk memperoleh persepsi wajib pajak mengenai sistem administrasi perpajakan modern terhadap kepatuhan wajib pajak. Kuesioner dibagikan oleh peneliti dengan cara membagikan secara langsung kepada responden dan juga melalui google form. 2) Wawancara, merupakan salah satu cara pengumpulan data, peneliti meggunakan wawancara semiterstruktur yang dimana pelaksanaannya lebih bebas dibandingkan wawancara terstruktur. 3) Dokumentasi, merupakan teknik penelitian dimana pengumpulan data-data yang diperlukan sehubungan dengan penelitian berupa data jumlah wajib pajak yang terdaftar di KPP Pratama Kendari.

\section{Metode Analisis Data}

\section{Analisis Deskriptif}

Deskriptif variabel penelitian bertujuan untuk menginterprestasikan mengenai distribusi frekuensi jawaban responden. Berdasarkan data primer yang diperoleh, distribusi frekuensi masing-masing jawaban dikelompokkan sesuai dengan indikator dan item jawaban. Skala yang digunakan adalah skala likert yang mempunyai skor 1 sampai 5. Nilai rata-rata pembobotan atau nilai skor jawaban responden yang diperoleh diklasifikasikan ke dalam rentang skala kategori nilai (Solimun,2017) yang disajikan sebagai berikut:

$$
\begin{aligned}
& 1-1,8=\text { Sangat Rendah / Tidak Baik } \\
& 1,8>-2,6=\text { Rendah / Kurang Baik } \\
& 2,6>-3,4=\text { Cukup Tinggi / Cukup Baik } \\
& 3,4>-4,2=\text { Tinggi / Baik } \\
& 4,22>\quad=\text { Sangat Tinggi / Sangat Baik }
\end{aligned}
$$




\section{Analisis Inferensial \\ Uji Kualitas Data}

Metode analisis yang digunakan dalam penelitian ini yaitu analisis deskriptif, uji kenormalan data, pengujian asumsi klasik berupa uji heteroskedastisitas, uji auto korelasi, serta analisis regresi linier sederhana dengan pemahaman sebagai berikut:

\section{- Uji Validitas}

Uji validitas digunakan apakah suatu instrument valid atau tidak dalam kuesioner. Suatu alat ukur dikatakan valid apakah dapat menjawab secara cermat tentang variabel yang diukur. Suatu kuesioner dikatakan valid jika pertanyaan pada kuesioner mampu mengungkapkan sesuatu yang akan diukur oleh kuesioner tersebut. Suatu kuesioner dinyatakan valid apabila $r$ hitung > $r$ tabel (Ghozali,2018).

\section{- Uji Reliabilitas}

Uji reabilitas dilakukan dengan tujuan untuk menunjukkan konsistensi suatu alat ukur dalam mengukur subjek yang sama, apabila hasil pengukuran menunjukkan hasil yang relative sama terdapat subjek yang sama selama beberapa kali maka alat ukur tersebut dapat dikatakan reliabel. Suatu alat ukur dapat dikatakan reliabel jika menunjukkan nilai Cronbach alpha lebih besar daripada 0,60 menurut pendapat Ghozali (2018).

\section{Uji Asumsi Klasik}

Berkaitan dengan uji asumsi klasik dalam penelitian ini model analisis yang digunakan akan menghasilkan estimator yang tidak biasa apabila memenuhi beberapa asumsi klasik sebagai berikut :

\section{- Uji Normalitas}

Uji Normalitas bertujuan untuk menguji apakah dalam model regresi,variabel dependen dan independen keduanya mempunyai distribusi noral atau tidak. Uji normalitas data dilakukan dengan menggunakan uji Kolmogorov Smirnov dan PP plot standardized residual.

\section{- Uji Heteroskedastisitas}

Uji Heteroskedastisitas bertujuan menguji apakah dalam model regresi terjadi ketidaksamaan varian dari residual satu pengamatan ke pengamatan yang lain. Model regresi yang baik adalah yang Homoskedastisitas atau tidak terjadi Heteroskedastisitas (Ghozali,2018).

\section{- Uji Autokorelasi}

Uji autokorelasi bertujuan untuk menguji apakah dalam model regresi linear ada korelasi antara kesalahan pengganggu pada periode $t$ dengan kesalahan pengganggu pada periode $\mathrm{t}-1$.

\section{Uji Hipotesis}

Untuk membuktikan kebenaran hipotesis, dilakukan uji statistik terhadap hasil regresi linier sederhana tersebut, adapun uji hipotesis antara lain:

\section{- Uji t (Uji secara parsial)}

Uji statistik t pada dasarnya untuk mengetahui sebarapa jauh pengaruh variabel independen secara individual dalam menerangkan variasi variabel dependen. Untuk mengetahui ada atau tidaknya pengaruh setiap variabel independen secara individual terhadap variabel dependen digunakan tingkat signifikan 0,05. Jika nilai probabilitas lebih besar dari 0,05 maka tidak terdapat pengaruh dari variabel independen terhadap variabel dependen, sedangkan jika 
Jurnal Akuntansi dan Keuangan (JAK)

Volume 6, No. 2 Oktober Tahun 2021

Page: 1 - 14

http://ojs.uho.ac.id/index.php/jak-uho/issue/archive

e-ISSN: 2088-4656

nilai probabilitas lebih kecil dari 0,05 maka terdapat pengaruh dari variabel independen terhadap variabel dependen (Ghozali,2018).

\section{Uji Koefisien Determinasi (R2)}

Uji koefisien determinasi digunakan untuk mengukur kemampuan model regresi dalam menerangkan variasi variabel dependen. Nilai R2 kecil berarti kemampuan variabel independen dalam menjelaskan variasi variabel dependen amat terbatas.

\section{Uji Regresi Linier Sederhana}

Adapun untuk menganalisis data yang telah diperoleh, penelitian menggunakan metode analisis regresi linier sederhana.Wijaya (2012) menjelaskan bahwa analisis regresi bertujuan menganalisis besarnya pengaruh variabel bebas (independen) terhadap variabel terikat (dependen).

\section{HASIL DAN PEMBAHASAN}

\section{Hasil Penelitian}

- Tingkat Pengembalian Kuesioner

Tabel 4.1 Tingkat Pengembalian Kuesioner

\begin{tabular}{|l|c|}
\hline \multicolumn{1}{|c|}{ Keterangan } & Jumlah \\
\hline Kuesioner yang disebar & 100 \\
\hline Kuesioner yang tidak dikembalikan & 0 \\
\hline Kuesioner yang dikembalikan & 100 \\
\hline Kuesioner yang digugurkan (tidak lengkap) & 0 \\
\hline Kuesioner yang digunakan & 100 \\
\hline Tingkat pengembalian kuesioner yang digunakan & $100 \%$ \\
\hline
\end{tabular}

Sumber : Data Primer diolah, 2021

- Hasil Uji Validitas dan Reliabilitas

Tabel 4.2

Hasil Uji Validitas dan Uji Reliabilitas

\begin{tabular}{|l|c|c|c|c|c|c|}
\hline \multicolumn{1}{|c|}{ Indikator Variabel } & $\begin{array}{c}\text { Item } \\
\text { Pertanyaan }\end{array}$ & $\begin{array}{c}\text { Koefisien } \\
\text { Korelasi }\end{array}$ & Sig. & Ket. & $\begin{array}{c}\text { Cronbach's } \\
\text { Alpha }\end{array}$ & Ket. \\
\hline Variabel Sistem Administrasi Perpajakan Modern (X1) \\
\hline Basis Teknologi & X1.1.1 & 0,776 & 0,000 & Valid & & \\
(X1.1) & X1.1.2 & 0,840 & 0,000 & Valid & 0,896 & Reliabel \\
& X1.1.3 & 0,901 & 0,000 & Valid & & \\
\hline \multirow{2}{*}{ Integrasi Data (X1.2) } & X1.2.1 & 0,821 & 0,000 & Valid & & \\
& X1.2.2 & 0,809 & 0,000 & Valid & 0,847 & Reliabel \\
\hline \multirow{2}{*}{ Memetakan Wajib } & X1.2.3 & 0,742 & 0,000 & Valid & & \\
Pajak (X1.3) & X1.3.2 & 0,848 & 0,000 & Valid & & \\
\hline \hline
\end{tabular}


Jurnal Akuntansi dan Keuangan (JAK)

Volume 6, No. 2 Oktober Tahun 2021

Page: 1 - 14

http://ojs.uho.ac.id/index.php/jak-uho/issue/archive

e-ISSN: 2088-4656

\begin{tabular}{|c|c|c|c|c|c|c|}
\hline \multicolumn{7}{|c|}{ Variabel Kepatuhan Wajib Pajak (Y1) } \\
\hline & Y1.1.1 & 0,846 & 0,000 & Valid & \multirow{4}{*}{0,938} & \multirow{4}{*}{ Reliabel } \\
\hline Aspek Ketepatan & Y1.1.2 & 0,888 & 0,000 & Valid & & \\
\hline \multirow[t]{2}{*}{ Waktu (Y1.1) } & Y1.1.3 & 0,904 & 0,000 & Valid & & \\
\hline & Y1.1.4 & 0,862 & 0,000 & Valid & & \\
\hline \multirow{4}{*}{$\begin{array}{l}\text { Aspek Income Atau } \\
\text { Penghasilan Wajib } \\
\text { Pajak (Y1.2) }\end{array}$} & Y1.2.1 & 0,830 & 0,000 & Valid & \multirow{4}{*}{0,883} & \multirow{4}{*}{ Reliabel } \\
\hline & Y1.2.2 & 0,796 & 0,000 & Valid & & \\
\hline & Y1.2.3 & 0,831 & 0,000 & Valid & & \\
\hline & Y1.2.4 & 0,717 & 0,000 & Valid & & \\
\hline Aspek Pengenaan & Y1.3.1 & 0,839 & 0,000 & Valid & \multirow{2}{*}{0,891} & \multirow{2}{*}{ Reliabel } \\
\hline Sanksi (Y1.3) & Y1.3.2 & 0,900 & 0,000 & Valid & & \\
\hline Aspek Pembayaran & Y1.4.1 & 0,893 & 0,000 & Valid & \multirow{2}{*}{0,926} & \multirow{2}{*}{ Reliabel } \\
\hline $\begin{array}{l}\text { Dan Aspek Kewajiban } \\
\text { Pembukaan (Y1.4) }\end{array}$ & $\mathrm{Y} 1.4 .2$ & 0,918 & 0,000 & Valid & & \\
\hline
\end{tabular}

Sumber : Data Primer diolah, 2021

Hasil uji validitas dan reliabilitas variabel Sistem Administrasi Perpajakan Modern (X) pada Tabel 4.2 menunjukkan semua indikator pada variabel sistem administrasi perpajakan modern menunjukkan hasil yang valid dan reliabel. Keputusan ini diambil karena nilai koefisien korelasi lebih dari 0,30 dan hasil cronbach's alpha lebih dari 0,60 dengan tingkat sangat signifikan $(0,000)$.

\section{- Karateristik Responden}

Tabel 4.3

Karakteristik Responden Wajib Pajak Orang Pribadi

\begin{tabular}{|l|l|l|c|c|}
\hline NO & \multicolumn{2}{|c|}{ Karateristik Responden } & Jumlah & Persentase \\
\hline \multirow{3}{*}{1.} & \multirow{3}{*}{ Menurut Jenis Kelamin } & Laki-laki & 46 & $46 \%$ \\
\cline { 3 - 5 } & & Perempuan & 54 & $54 \%$ \\
\cline { 3 - 5 } & & Total & $\mathbf{1 0 0}$ Orang & $\mathbf{1 0 0 \%}$ \\
\hline \multirow{4}{*}{2.} & \multirow{3}{*}{ Menurut Usia } & $<30$ Tahun & 31 & $31 \%$ \\
\cline { 3 - 5 } & & $30-50$ Tahun & 59 & $59 \%$ \\
\cline { 3 - 5 } & & > 50 Tahun & 10 & $10 \%$ \\
\cline { 3 - 5 } & Total & $\mathbf{1 0 0}$ Orang & $\mathbf{1 0 0 \%}$ \\
\hline \multirow{4}{*}{3.} & Menurut Pengetahuan & Brevet Pajak & 2 & $2 \%$ \\
\cline { 3 - 5 } & Pajak & Penyuluhan Pajak & 23 & $23 \%$ \\
\cline { 3 - 5 } & & Tidak Ada & 21 & $21 \%$ \\
\cline { 3 - 5 } & Lainnya & $\mathbf{1 0 0}$ & $\mathbf{1 0 0 \%}$ \\
\cline { 3 - 5 } & Total & & \\
\hline
\end{tabular}

Sumber : Data Primer diolah, 2021 
Jurnal Akuntansi dan Keuangan (JAK)

Volume 6, No. 2 Oktober Tahun 2021

Page: 1 - 14

http://ojs.uho.ac.id/index.php/jak-uho/issue/archive

e-ISSN: 2088-4656

- Hasil Uji Asumsi Klasik

- Uji Normalitas

\section{Gambar 4.1 Normal Probability Plot}

Gambar 4.2 Histogram
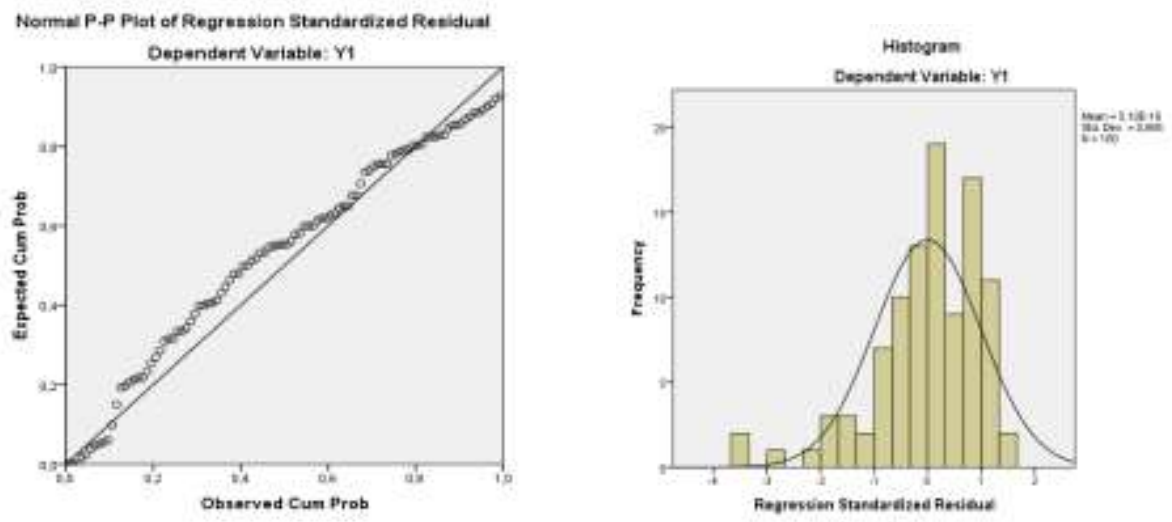

\section{Sumber : Data Primer diolah,2021}

Berdasarkan Gambar 4.1 grafik normal probability plot diatas, terlihat bahwa titiktitik menyebar di sekitar garis diagonal, serta penyebarannya mengikuti arah garis diagonal. Sehingga model regresi layak dipakai untuk prediksi kepatuhan wajib pajak pada Kantor Pelayanan Pajak Pratama kendari berdasarkan masukan variabel bebasnya.

\section{- Uji Heterokedastisitas}

\section{Gambar 4.3 Hasil Uji Heteroskedastisitas}

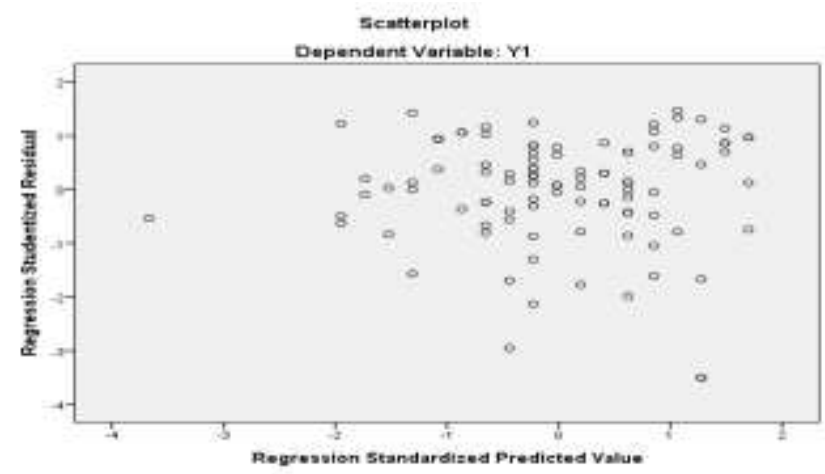

Sumber : Data Primer diolah, 2021

Berdasarkan grafik scatter plot terlihat secara visual nilai residual dan nilai prediksinya tidak membentuk pola tertentu (acak), sehingga dapat dikatakan bahwa model regresi dalam penelitian ini terbebas dari masalah heteroskedastisitas. 
Jurnal Akuntansi dan Keuangan (JAK)

Volume 6, No. 2 Oktober Tahun 2021

Page: 1 - 14

http://ojs.uho.ac.id/index.php/jak-uho/issue/archive

e-ISSN: 2088-4656

- Uji Autokorelasi

Tabel 4.6 Hasil Uji Autokorelasi

Model Summary ${ }^{b}$

\begin{tabular}{|c|c|c|c|c|c|c|c|c|c|c|}
\hline \multirow[t]{2}{*}{ Model } & \multirow[t]{2}{*}{$\mathrm{R}$} & \multirow[t]{2}{*}{ R Square } & \multirow{2}{*}{$\begin{array}{c}\text { Adjusted R } \\
\text { Square }\end{array}$} & \multirow{2}{*}{$\begin{array}{l}\text { Std. Error } \\
\text { of the } \\
\text { Estimate }\end{array}$} & \multicolumn{5}{|c|}{ Change Statistics } & \multirow{2}{*}{$\begin{array}{l}\text { Durbin- } \\
\text { Watson }\end{array}$} \\
\hline & & & & & $\begin{array}{l}\text { R Square } \\
\text { Change }\end{array}$ & $\begin{array}{c}\mathrm{F} \\
\text { Change }\end{array}$ & df1 & df2 & $\begin{array}{l}\text { Sig. F } \\
\text { Change }\end{array}$ & \\
\hline 1 &, $625^{\mathrm{a}}$ & ,391 & ,385 & ,44693 & ,391 & 62,969 & 1 & 98 & ,000 & 1,537 \\
\hline
\end{tabular}

Sumber : Data Primer diolah, 2021

Hasil uji pada tabel 4.6 menunjukkan nilai pada angka Durbin-Watson (D-W) adalah 1,537 dimana angka tersebut berada diantara -2 sampai +2 yang berarti tidak terjadi autokorelasi.

- Analisis Data dan Pengujian Hipotesis

- Analisis Regresi Linear Sederhana

Tabel 4.7 Hasil Analisis Regresi

Coefficients $^{\mathrm{a}}$

\begin{tabular}{|c|c|c|c|c|c|c|c|c|}
\hline \multirow[t]{2}{*}{ Model } & \multicolumn{2}{|c|}{$\begin{array}{c}\text { Unstandardized } \\
\text { Coefficients }\end{array}$} & \multirow{2}{*}{$\begin{array}{l}\text { Standardized } \\
\text { Coefficients } \\
\text { Beta }\end{array}$} & \multirow[t]{2}{*}{$\mathrm{t}$} & \multirow[t]{2}{*}{ Sig. } & \multicolumn{3}{|c|}{ Correlations } \\
\hline & $\mathrm{B}$ & Std. Error & & & & $\begin{array}{l}\text { Zero- } \\
\text { order }\end{array}$ & Partial & Part \\
\hline (Constant) & 1,134 & ,360 & & 3,150 & ,002 & & & \\
\hline $\mathrm{X} 1$ & ,688 & ,087 & ,625 & 7,935 & ,000 & ,625 & ,625 & ,625 \\
\hline
\end{tabular}

Sumber : Data Primer Diolah, 2021

Dari tabel 4.7 di atas dapat diperoleh persamaan sebagai berikut :

$$
\mathrm{Y}=1,134+0,688 \mathrm{X}+\varepsilon
$$

Berdasarkan persamaan regresi diatas, konstanta (a) adalah sebesar 1,134 dan koefisien regresi sistem administrasi perpajakan modern sebesar 0,688 kali. Hal ini berarti bahwa jika tidak ada perubahan variabel sistem administrasi perpajakan modern atau sistem administrasi perpajakan modern diasumsikan konstan atau sama dengan nol, maka variabel terikat kepatuhan wajib pajak akan mengalami kenaikan sebesar 1,134, dan apabila variabel sistem administrasi perpajakan modern terjadi kenaikan satu kali, maka variabel terikat kepatuhan wajib pajak akan mengalami kenaikan sebesar 0,688. Hal ini menunjukkan bahwa Sistem Administrasi Perpajakan Modern (X) berpengaruh positif terhadap Kepatuhan Wajib Pajak (Y). 
Jurnal Akuntansi dan Keuangan (JAK)

Volume 6, No. 2 Oktober Tahun 2021

Page: 1 - 14

http://ojs.uho.ac.id/index.php/jak-uho/issue/archive

e-ISSN: 2088-4656

\section{- Pengujian Hipotesis}

\section{Tabel 4.8 Ringkasan Uji t dan Koefisien Determinasi}

\begin{tabular}{|c|c|c|c|c|}
\hline Variabel & $\mathrm{t}_{\text {-hitung }}$ & $\mathrm{t}_{\text {tabel }}$ & Sig. & R.Square \\
\hline $\mathrm{X} 1$ & 7,935 & 1,984 & 0.000 & 0.391 \\
\hline
\end{tabular}

Sumber : Data Primer Diolah, 2021

Pengujian hipotesis dilakukan dengan membandingkan nilai t-hitung dengan t-tabel. Apabila t-hitung > t-tabel maka $\mathrm{H} 1$ berpengaruh atau $\mathrm{H} 0$ tidak berpengaruh. Sebaliknya, apabila t-hitung < t-tabel maka H1 tidak berpengaruh atau H0 berpengaruh. Dari tabel 4.8 menunjukkan bahwa $\mathrm{t}_{\text {-hitung }}$ sebesar 7,935 > dari $\mathrm{t}_{\text {tabel }}$ yaitu sebesar 1,984 atau dengan tingkat signifikan sebesar $0,000<$ dari $\alpha=0,05$, maka dari hasil pengujian tersebut dapat disimpulkan bahwa $\mathrm{H}_{1}$ diterima.

Berdasarkan tabel 4.8 diketahui besarnya R2 (R-Square)= 0,391. Hal ini menunjukkan bahwa besarnya kontribusi langsung variabel sistem administrasi perpajakan modern (X) terhadap kepatuhan wajib pajak (Y) di kantor pelayanan pajak pratama kendari sebasar 39,1\%. Hal ini berarti bahwa ada variabel lain sebesar 60,9\% yang mempengaruhi variabel $\mathrm{Y}$ yang belum diteliti dalam penelitian ini.

\section{Pembahasan}

Berdasarkan penelitian ini dapat dilihat bahwa pada KPP Pratama Kendari tingkat kepatuhan wajib pajak orang pribadi belum maksimal karena mengalami penurunan pada tahun 2016 sampai 2017. Hal ini disebabkan karena kurangnya pemahaman wajib pajak terhadap ketentuan umum dan tata cara perpajakan dan juga kurangnya pemahaman tentang E-system yang menjadi faktor kurangnya wajib pajak dalam memenuhi kewajibannya. Tetapi pada tahun 2018 sampai 2019 mengalami peningkatan karena wajib pajak orang pribadi mulai mengetahui tata cara menggunakan aplikasi perpajakan dan menganggap bahwa dalam menggunakan aplikasi dalam melapor dan membayar pajak lebih efektif karena lebih mudah, dapat menghemat waktu, biaya dan juga tenaga.

Pengaruh sistem administrasi perpajakan modern terhadap kepatuhan wajib pajak pada Kantor Pelayanan Pajak Pratama Kendari dapat diketahui dengan menggunakan pengujian statistik. Dari hasil penelitian ini tentunya tidak lepas dari jawaban responden atas persepsi mereka tentang sistem administrasi perpajakan modern terhadap kepatuhan wajib pajak pada Kantor Pelayanan Pajak Pratama Kendari.

Indikator dalam variabel sistem administrasi perpajakan modern terdiri atas tiga indikator yaitu integrasi data menjadi indikator yang paling mendominasi dalam meningkatkan kepatuhan wajib pajak yang didukung dengan indikator lainnya yaitu basis teknologi dan memetakan wajib pajak yang mana semuanya dikategorikan baik dalam meningkatkan kepatuhan wajib pajak dalam mematuhi kewajiban dalam membayar pajak yang dilihat dari indikator kepatuhan wajib pajak yaitu aspek ketepatan waktu, aspek pembayaran dan aspek kewajiban pembukuan, aspek law enforcement (pengenaan sanksi), aspek income (penghasilan wajib pajak). 
Persepsi wajib pajak menganggap bahwa dengan adanya integrasi data pada KPP Pratama Kendari wajib pajak terdorong untuk jujur dan taat dalam memenuhi kewajiban pajaknya karena integrasi data merupakan konektivitas data wajib pajak dengan sistem DPJ yang diolah melalui sistem informasi sehingga data yang dilaporkan wajib pajak dalam SPT dapat dibandingkan dengan data yang masuk dalam sistem informasi. Hal ini menjadi alat bantu untuk memonitoring kepatuhan wajib pajak. Indikator lainnya yaitu basis teknologi yang memicu wajib pajak untuk memenuhi kewajibannya karena dengan adanya sistem administrasi yang berbasis teknologi terkini, wajib pajak lebih mudah dan praktis dalam membayar pajak dengan menggunakan aplikasi pajak online. Dan indikator memetakan wajib pajak yang mana juga dapat meningkatkan kepatuhan wajib pajak karena dengan adanya pemetaan wajib pajak atau pengelompokkan dalam administrasi pajak yang dapat mengakomodasi tentunya akan menjadi alat dalam mendongkrak penerimaan kedepannya dan tiap wajib pajak akan mendapatkan perlakuan yang sesuai dengan perilakunya. Hal ini menunjukkan bahwa dari indikator-indikator tersebut, sistem administrasi perpajakan modern memberikan kemudahan bagi wajib pajak dalam melaporkan pajaknya.

Sistem administrasi perpajakan modern dapat meningkatkan kepatuhan wajib pajak karena dengan adanya teknologi yang bersifat modern dapat memberikan kemudahan dan praktis bagi wajib pajak untuk memenuhi kewajibannya. Hal ini wajib pajak melakukan pembayaran dan juga melaporkan pajaknya secara online, wajib pajak tidak perlu lagi ke kantor pajak untuk antri dalam membayar maupun melaporkan pajaknya. Sebagian besar wajib pajak orang pribadi di KPP pratama kendari sudah menggunakan aplikasi dan kemungkinan yang ke kantor pajak biasanya wajib pajak baru untuk konsultasi atau keperluan lainnya. Dengan demikian, apabila sistem administrasi perpajakan modern berjalan dengan baik maka akan meningkatkan tingkat kepatuhan wajib pajak.

Hasil penelitian ini sejalan dengan penelitian Haris (2018) dan Duwiri (2020) yang menjelaskan bahwa sistem administrasi perpajakan modern berpengaruh terhadap kepatuhan wajib pajak. Artinya bahwa apabila sistem administrasi perpajakan modern berjalan dengan baik maka tingkat kepatuhan wajib pajak akan semakin meningkat.

\section{KESIMPULAN, IMPLIKASI, KETERBATASAN DAN REKOMENDASI}

\section{Kesimpulan}

Kesimpulan dari hasil penelitian dan pembahasan yang dikemukakan sebelumnya dalam penelitian ini adalah sistem administrasi perpajakan modern berpengaruh signifikan dan positif terhadap kepatuhan wajib pajak pada kantor pelayanan pajak pratama kendari. Hal ini didukung dari hipotesis yang diajukan dalam penelitian ini terbukti bahwa tingkat signifikan $0,000<0,05$ artinya bahwa apabila sistem administrasi perpajakan modern berjalan dengan baik maka akan meningkatkan kepatuhan wajib pajak dalam memenuhi kewajibannya dalam membayar pajak.

\section{Implikasi}

Sistem administrasi perpajakan modern terbukti memberikan pengaruh terhadap kepatuhan wajib pajak orang pribadi. Oleh karena itu, apabila sistem administrasi perpajakan modern berjalan dengan baik maka kepatuhan wajib pajak orang pribadi akan semakin meningkat. 
Jurnal Akuntansi dan Keuangan (JAK)

Volume 6, No. 2 Oktober Tahun 2021

Page: 1 - 14

http://ojs.uho.ac.id/index.php/jak-uho/issue/archive

e-ISSN: 2088-4656

\section{Keterbatasan}

1. Subjek pada penelitian ini hanya pada wajib pajak orang pribadi, diharapkan pada peneliti selanjutnya untuk menambah subjek penelitian pada wajib pajak badan.

2. Penelitian ini terbatas pada satu variabel independen saja, diharapkan pada peneliti selanjutnya untuk menambahkan variabel independen lainnya.

\section{Rekomendasi}

- Bagi KPP Pratama Kendari

KPP Pratama Kendari disarankan sebaiknya memberikan sosialisasi pada wajib pajak dan juga melakukan pelatihan yang lebih atraktif terkait program sistem administrasi perpajakan modern pada wajib pajak.

- Bagi Wajib Pajak

Wajib Pajak disarankan untuk lebih efektif mengikuti perkembangan-perkembangan terkini terkait perpajakan termasuk pada program-program baru yang dikeluarkan oleh Direktorat Jendral Pajak dengan mengikuti sosialisasi dan pelatihan.

- Bagi Penelitian Selanjutnya

Dalam penelitian ini diharapkan pada peneliti selanjutnya agar meneliti lebih lanjut variabel-variabel lain yang memiliki pengaruh terhadap kepatuhan wajib pajak, misalnya variabel sosialisasi atau pelatihan. Selain itu, disarankan peneliti selanjutnya juga dapat meneliti tentang keterkaitan antara sistem administrasi perpajakan modern dan penerimaan pajak.

\section{Daftar Pustaka}

Abimayu,Anggito, 2003. Reformasi Perpajakan, Jakarta : Salemba Empat.

Awaluddin, Ishak. 2017. Perpajakan "Pembahasan Sesuai Aturan Pelaksanaan Perpajakan Terbaru 2017”. Yokyakarta: Penerbit K-Media.

Ghozali, Imam. 2016. Aplikasi Analisis Multivariate dengan Program IBM SPS 19 semarang: Universitas Diponegoro.

Gunadi. 2006. Reformasi Administrasi Perpajakan Dalam Rangka Kontribusi Menuju Good Governance. Guru Besar Perpajakan FISIP UI. Jakarta.

Nasucha, Chaizi. 2004. Reformasi Administrasi Publik: Teori dan Praktik, PT Gramedia Widiasarana Indonesia, Jakarta.

Pandiangan, Liberti. 2008. Modernisasi dan Reformasi Pelayanan Perpajakan, PT Elex Media Komputindo, Jakarta.

Rahayu, Siti Kurnia. 2010. Perpajakan Indonesia. Yogyakarta: Graha Pustaka

Resmi, Siti. 2019. Perpajakan. Teori dan Kasus Edisi 11. Jakarta: Selempa Empat.

Sari, Diana. 2013. Konsep Dasar Perpajakan. Bandung: PT Refika Adimata.

Sarunan, Widya K. 2015. Pengaruh Pengaruh Modernisasi Sistem Administrasi Perpajakan Terhadap Kepatuhan Wajib Pajak Orang Pribadi dan Wajib Pajak Badan pada Kantor Pelayanan Pajak Pratama Manado. Jurnal EMBA Vol.3 No.4.

Sofyan, Masyur Taufan. 2005. Pengaruh Penerapan Sistem Administrasi Perpajakan Modern terhadap Kepatuhan Wajib Pajak pada Kantor Pelayanan Pajak di Lingkungan Kantor Wilayah Direktorat Jenderal Pajak Wajib Pajak Besar. Skripsi Sekolah Tinggi Akuntansi Negara, Jakarta. 
Jurnal Akuntansi dan Keuangan (JAK)

Volume 6, No. 2 Oktober Tahun 2021

Page: 1 - 14

http://ojs.uho.ac.id/index.php/jak-uho/issue/archive

e-ISSN: 2088-4656

Solimun, Adji Achmad Rinaldo dan Samingun Handoyo. 2017. Perancangan dan Pengujian Kuesioner Serta Transformasi Skor Menjadi Skala Berbasis MSI, SRI dan Rasch Model. Program Studi Statistika Jurusan Matematika Fakultas Matematika dan Ilmu Pengetahuan Alam Universitas Brawijaya

Sugiyono, 2015. Metode Penelitian Pendidikan, Pendekatana Kuantitatif, Kualitatif, dan R\&D. Bandung: Alfabeta.

2017. Metode Penelitian Kuantitatif, Kualitatif, dan R \& D. Bandung: Alfabeta. 